\title{
Jurassic rhynchonellide brachiopods from the Jordan Valley
}

\author{
Howard R. Feldman, Mena Schemm-Gregory, Fayez Ahmad, and Mark A. Wilson
}

Acta Palaeontologica Polonica 57 (1), 2012: 191-204 doi: http://dx.doi.org/10.4202/app.2010.0092

Jurassic rhynchonellide brachiopods from the Jordan Valley are herein revised and new taxa are added to the faunal list. In this study of Jurassic rhynchonellides from Wadi Zarqa, northwestern Jordan, we recognize the following taxa: Eurysites rotundus, Cymatorhynchia quadriplicata, Daghanirhynchia triangulata, D. angulocostata, Pycnoria magna, Schizoria elongata, and Schizoria cf. intermedia. The following new taxa are described: Daghanirhynchia susanae sp. nov. and Amydroptychus markowitzi sp. nov. The Middle Jurassic Mughanniyya Formation of northwest Jordan is dominated by limestone beds. The sedimentary environment is interpreted as neritic, light, and nutrient-rich resulting in high faunal diversity. The high rhynchonellide endemism of this fauna is yet another confirmation of pronounced Middle Jurassic endemism along the southern Tethyanmargin of the Ethiopian Province. Brachiopods of the Jordanian Mughanniyya Formation can be correlated with the fauna of the Aroussiah Formation in Sinai and the Zohar and Matmor formations in Southern Israel.

Key words: Brachiopoda, Rhynchonellida, Jurassic, Mughanniyya Formation, Jurassic, Jordan.

Howard R. Feldman [feldspar4@optonline.net], Division of Palaeontology (Invertebrates), American Museum of Natural History, New York, NY 10024, USA, Mena Schemm-Gregory [Mena.Schemm-Gregory@ dct.uc.pt ], Centro de Geociências da Universidade de Coimbra, Largo Marquês do Pombal, P-3000-272 Coimbra, Portugal, Ahmad Fayez [fayezahmad3@ hotmail.com ], Faculty of Natural Resources and Environment, Department of Earth and Environmental Sciences, The Hashemite University, P.O. Box 150459, 13115 Zarqa, Jordan, and Mark A. Wilson [mwilson@wooster.edu], Department of Geology, The College of Wooster, 944 College Mall, Wooster, OH 44691, USA.

This is an open-access article distributed under the terms of the Creative Commons Attribution License (for details please see creativecommons.org), which permits unrestricted use, distribution, and reproduction in any medium, provided the original author and source are credited. 
PoF Full text (656.4 kB) 